\title{
Impact of dry needling and ischemic pressure in the myofascial syndrome: controlled clinical trial ${ }^{1}$
}

\author{
Impacto do agulhamento seco e compressão isquêmica \\ na síndrome miofascial: ensaio clínico controlado
}

\section{Rebeka Borba da Costa Santos ${ }^{[a]}$, Maíra Izzadora Souza Carneiro ${ }^{[b]}$, Déborah Marques de Oliveira ${ }^{[b]}$, Adriana Baltar do Rêgo Maciel ${ }^{[c]}$, Kátia Karina do Monte-Silva ${ }^{[\mathrm{d}]}$, Maria das Graças Rodrigues Araújo ${ }^{[\mathrm{e}]}$}

[a] Physiotherapist, MSc, Programa de Pós-Graduação em Fisioterapia, Universidade Federal de Pernambuco, Recife, PE Brazil, e-mail: rebeka_borba@hotmail.com

[b] Physiotherapist, Programa de Pós-Graduação em Fisioterapia, Universidade Federal de Pernambuco, Recife, PE - Brazil, e-mails: mairasouza77@gmail.com; deby.marques@gmail.com

[c] Physiotherapist, Programa de Pós-Graduação em Neuropsiquiatria e Ciências do Comportamento, Universidade Federal de Pernambuco, Recife, PE - Brazil, e-mail: adrianabaltarmaciel@gmail.com

[d] PhD, professor, Departamento de Fisioterapia, Programa de Pós-Graduação em Fisioterapia, Universidade Federal de Pernambuco, Recife, PE - Brazil, e-mail: monte.silvakk@gmail.com

[e] PhD, professor, Laboratório de Cinesioterapia e Recursos Terapêuticos Manuais, Departamento de Fisioterapia, Universidade Federal de Pernambuco, Recife, PE - Brazil, e-mail: mgrodriguesaraujo@hotmail.com

\section{Abstract}

Introduction: Musculoskeletal pain is a common clinical condition and about $10 \%$ of the population have musculoskeletal disorder. Objective: The aim of this study was to evaluate whether ischemic pressure and dry needling techniques are able to reduce the pain of patients with myofascial pain syndrome. Method: 22 patients aged 20-75 years were randomized into 3 groups: ischemic pressure (IPG = 8), dry needling (DNG = 7) and control $(C G=7)$. Patients in the IPG and DNG were assessed before and after 10 intervention sessions, which

\footnotetext{
3 Registration number REBEC: RBR-78bq5x.
} 
occurred 3 times per week. The CG was assessed initially and reassessed three weeks later. The assessment of pain was done through Visual Analogic Scale (VAS) and quality of life through WHOQOL-BREF (5 domains: global, physical, psychological, social and environmental). Results: There was no significant difference for clinical and demographic data of all groups at baseline, except for age ( $p=0.042)$. The results of the VAS expressed that IPG had pain relief in most sessions, the same was not observed for DNG. Comparing the 2 groups was obtained difference in the $4^{\text {th }}$ and $8^{\text {th }}$ sessions. The results of the WHOQOL-BREF showed that the three groups had a significant increase in the psychological domain. The same was not true for global domains, physical, environmental and social. Conclusion: Ischemic pressure and dry needling were able to reduce the pain of patients and also change their quality of life, specifically the psychological aspect.

Keywords: Musculoskeletal pain. Musculoskeletal manipulations. Low back pain. Neck pain.

\section{Resumo}

Introdução: A dor musculoesquelética é uma condição clínica comum e cerca de 10\% da população possui distúrbio do sistema musculoesquelético. Objetivo: O objetivo deste estudo foi avaliar se a compressão isquêmica e o agulhamento seco são técnicas capazes de reduzir a dor de pacientes com síndrome miofascial. Método: 22 pacientes com idade entre 20-75 anos foram randomizados em 3 grupos: compressão isquêmica $(G C I=8)$, agulhamento seco $(G A S=7)$ e controle $(G C=7)$. Os pacientes do GCI e GAS foram avaliados antes e após as 10 sessões terapêuticas, que ocorreram 3 vezes por semana. O GC foi avaliado inicialmente e reavaliado 3 semanas depois. Para mensuração da dor usou-se a Escala Visual Analógica (EVA) e da qualidade de vida o WHOQOLBREF (5 domínios: global, físico, psicológico, social e meio ambiente). Resultados: $A$ análise dos dados clínicos e demográficos mostrou que não houve diferença entre os grupos, exceto para idade $(p=0,042)$. Os resultados da EVA expressaram que o GCI teve redução da dor na maioria das sessões, o mesmo não se observou para o GAS. Comparando os 2 grupos obteve-se diferença na $4^{a}$ e e $8^{\underline{a}}$ sessões. Os resultados do WHOQOL-BREF demonstraram que os 3 grupos tiveram um aumento significante no domínio psicológico. O mesmo não ocorreu para os domínios global, físico, meio ambiente e social. Conclusão: A compressão isquêmica e o agulhamento seco foram capazes de reduzir a dor dos pacientes e também intervir na sua qualidade de vida, especificamente no aspecto psicológico.

Palavras-chave: Dor musculoesquelética. Manipulações musculoesqueléticas. Dor lombar. Dor cervical.

\section{Introduction}

Musculoskeletal pain is a commom clinical condition and around $10 \%$ of the population have one or more disorders of the musculoskeletal system (1, $2,3,4)$. The myofascial pain syndrome is the most common musculoskeletal disfunction (5).

This syndrome is characterized for a localized or referred muscle pain that is originated in a myofascial trigger point (MTrP) (6). The term MTrP describes a nodule into a taut band localized mainly in the motor endplate, in which is formed a hypersensitive and painful zone $(5,7)$. However, the formation mechanisms of TPs are low understood. It is known that, the local muscle pain is related to the activation of muscular nociceptors for variety of endogenous substances including neuropeptides, arachidonic acid derivatives, inflammatory mediators and others. Hemodynamic disturbs are too involved in the pathophysiology of this disease, Hiraizumi (8) showed a reduction of the blood flow of the trapezius muscle in patients with chronic neck pain when compared with health people. More recently, the neurogenic theory, says that the TPs are secondary peripheral manifestations to a central sensitization caused by a primary pathology into a common neuronal field (1).

The therapeutic approach of the myofascial pain syndrome is extremely hard, due to the difficulty in the diagnosis, that occurs only $15 \%$ of the cases (9). The treatment for the myofascial pain syndrome is wide and has a lot of techniques being the most used: ischemic pressure (IP), dry needling (DN), wet needling, passive stretching, stretching and spray, TENS, massage (10), ultra-sound and laser $(5,11$, 
12). Into these techniques, the DN and IC seems to be very effectives in the treatment of the myofascial pain syndrome $(13,14,15)$.

The DN, a similar technique to acupuncture, is an effective treatment for pain relief. This technique can increase pain threshold and range of motion (ROM) of back pain. Hsieh et al. (14) has provided evidence that dry needle-evoked inactivation of a primary TrPs inhibits the activity in satellite TrPs situated in its zone of pain referral. For the IC, the physiological effects could be related with the hyperemic response after the compression period provide more blood flow in the tissue, thus suplly the oxygen and removes the catabolites $(16,17)$. Thus, this study compare the effectiveness of the DN and IC in the treatment of myofascial pain beyond the reduce of pain and analyzing the influence in the quality of life.

\section{Method}

Study design and subjects

We performed a single blind control trial. The present study was approved by the Research Ethics Committee (CAAE - 0313.0.172.000-09) and were performed in accordance with the Declaration of Helsinki. After have been informed about the experimental procedures and purpose of the study, all participants gave their written informed consent prior to the experiment. The patients were recruited in the physiotherapy ambulatory of Clínicas Hospital $(\mathrm{CH})$ and other centers of the University and at the local community. In this research, 22 patients of both gender, aged between 20-75 years who had spinal pain of myofascial origin more than 6 weeks were included. Patients that were using any medication to reduce the pain and/or have any effect in the skeletal muscle; were doing another physical method in the same period of the research; pregnant; patients with clinic evidence of organic disturbs (kidney disease, coronary artery syndrome, osteoporosis) and spinal disease (herniated disc, spondylolisthesis) were excluded.

\section{Experimental design}

All patients were divided through drawing in 3 groups: (i) dry needling group (DNG, $n=7$ ) which was underwent to the dry needling; (ii) ischemic pressure group (IPG, $\mathrm{n}=8$ ) which was underwent to the ischemic pressure and (iii) waiting list control group (CG, $n=7$ ) which did not receive any treatment. In order to perform a single blind study, four researchers participated in the study. Two examined the patients before and after the treatment sessions and was unaware of the treatment. Given the nature of the study, it will not be possible for the patients to be blinded. The others were involved in carrying out the treatment sessions. Patients were instructed not to report what assistance had been received during the sessions. The treatment was applied 3 times a week in 10 intervention sessions.

\section{Outcomes measures}

For the DNG and IPG, the evaluation was realized in 2 moments: before the beginning of treatment (T0) and after the end of treatment (T1), respecting the minimum interval of 24 hours after the last session. The CG was submitted to an initial evaluation (T0) and after 3 weeks to another evaluation (T1). For all groups anthropometric and clinical data were collected at baseline.

The primary outcome was the intensity pain. The secondary outcomes was the Short Form of WHO Quality of Life Questionnaire.

All groups were submitted to the same clinical evaluation. Initially, a manual inspection was realized through a deep sliding in all back musculature to localize the actives MTrP. The inspected musculature was sternocleidomastoid, scalene, trapezius, rhomboid muscles, levator scapulae, serratus posterior inferior, latissimus dorsi muscle, piriformis, quadratus lumborum and paraspinal. In this initial evalution, the pressure algometry was used to determine the principal and secondary MTrP. The algometry was done according to Fisher protocol (18) and the lower threshold MTrP was called principal MTrP (PMTrP) and the other, secondary MTrP (SMTrP).

For measurement of pain, the patient indicated, before and after each session, their degree of pain by Visual Analogic Scale (VAS) ranging from 0 to 10 where 0-2 is considered mild pain, 3-7 moderate and 8-10 severe (19). Furthermore, the VAS was applied also in the initial evaluation. The WHOQOL-BREF, developed by the WHOQOL-100, was used to measure the quality of life (20). The validity and reliability of Brazilian version 
have been confirmed (21). The WHOQOL-BREF consists of 26 items of 5 domains: physical, psychological, social relations, environmental and global. Each item is scaled from 1-5. Higher scores indicate more positive response to quality of life.

\section{Procedures}

Each session lasted 30 minutes, in the DNG, DN was applied during 15 minutes in principal MTrP and 15 minutes in the secondary MTrP. Application of the DN was done as described by HEISH (14). In the IPG, a pressure of $4 \mathrm{Kgf}$ was applied 3 times of 30 seconds in principal and secondary MTrP (22).

Following the research protocol, in both group others MTrP was selected in each session according with the patient's pain complaint, thus the application of the DN or IP was not realized only in the MTrP selected in the evaluation.

\section{Data analysis}

Descriptive statistics, including proportions for categorical variables, and means, standard deviations for continuous variables, were computed. In order to verify the groups homogeneity, the one-way ANOVA was applied for continuous variables (age, weight, initial score from VAS e WHOQOLl) and the Kruskal-wallis for the categoric variables (gender). For identify the changes in the pain perception (VAS) was applied the paired sample test to comparison intragroup and test $\mathrm{t}$ for independent sample for comparison between groups. The WHOQOL effect was tested by one-way ANOVA model, with intervention type as one factor (difference among groups) and Bonferroni post hoc test. A P value of $<0.05$ was considered statistically significant.

\section{Results}

Forty-seven patients with spinal pain of myofascial origin were enrolled through phone contact in the study. However, twelve contacts were lost. Thus, thirty-five subjects were screened for the study, being six were excluded. Twenty-nine patients were draw to one of three groups. Over a period of four weeks, seven participants dropped out spontaneously from the study for health or personal reasons or yet for consecutive lacks, three in the DNG, two in the CG and two in the IPG (Figure 1). The final sample consisted of twenty-two patients (7 in the DNG, 7 in the CG and 8 in the IPG). As shown in Table 1, three groups of patients were compared, since there were no statistical differences in demographic and clinical data among the groups at baseline (T0), except for age $(\mathrm{p}=0.042)$.

Figure 2 shows the VAS scores for two groups recorded before and after each session. Patients treated with pressure ischemic showed a significant reduction of pain score after the most sessions. For the DNG was observed no difference in mean pain reduction. In the comparison between groups this reduction was significant just in the $4^{\text {th }}$ and $8^{\text {th }}$ session.

DNG, CG and IPG showed a significant increase for physiological domain of WHOQOL-BREF. The physical, social relation, environmental and global domains of WHOQOL-BREF did not change after the intervention sessions (Table 2).

\section{Discussion}

According to the results presented, our study demonstrated clinical effective of dry needling and ischemic pressure in treatment of patients with chronic pain myofascial on improving pain perception and quality of life. These results seem to be due the increase of pain threshold after intervention sessions.

Previous study showed a reduction of pain intensity after sessions of ischemic pressure followed by sustained stretch $(22,23)$, our results demonstrated decrease of pain intensity after ischemic pressure sessions and no change after dry needling sessions. One explanation for this result was demonstrated by some research which showed that immediately after dry needling, some adverse effects can be happen such as pain, local hemorrhages, skin irritation and some physical discomfort $(2,24,25)$. Thus, the knowledge of these events explain the no change of pain intensity since the measurement of pain was done immediately after dry needling. On the other hand, poor descriptions about the adverse effects after ischemic pressure are found. Furthermore, another trials showed that ischemic pressure has the a similar therapeutic principle to deep massage and considered this technique the most effective manual method in the treatment of myofascial pain $(26,27,28)$. 


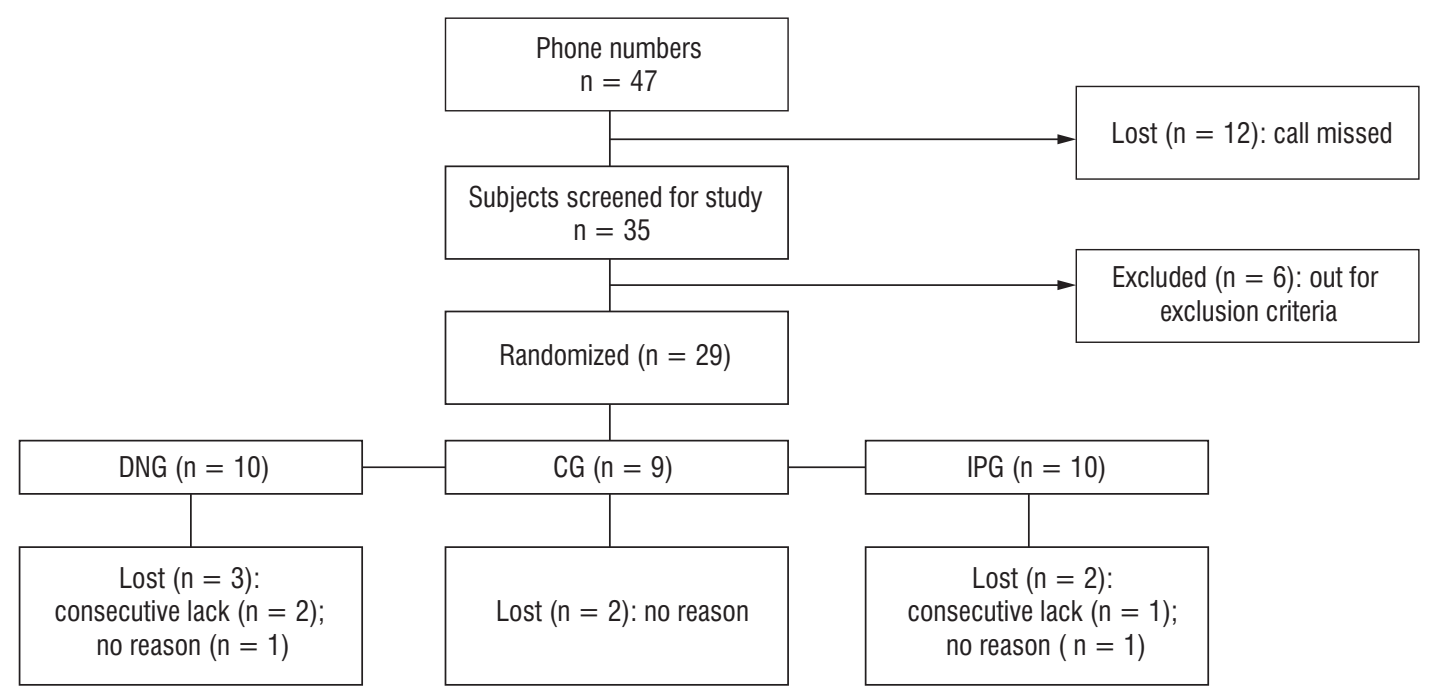

Figure 1 - Flow of the sample

Table 1 - Comparison of patient's characteristics and baseline data

\begin{tabular}{|c|c|c|c|c|}
\hline & DNG & IPG & CG & $\mathrm{p}$-value \\
\hline & $N=7$ & $N=8$ & $N=7$ & \\
\hline Gender Female/Male & $2 / 7$ & $4 / 4$ & $5 / 2$ & 0.707 \\
\hline Age (years) & $38.5 \pm 5.1$ & $24.5 \pm 2.7$ & $25.8 \pm 3.0$ & 0.042 \\
\hline Weight (kg) & $74.0 \pm 5.2$ & $61.2 \pm 5.3$ & $61.6 \pm 3.8$ & 0.247 \\
\hline Height (cm) & $168 \pm 0.0$ & $170 \pm 0.0$ & $168 \pm 0.0$ & 0.670 \\
\hline VAS score $(0-10)$ & $3.8 \pm 0.5$ & $4.7 \pm 0.9$ & $5.2 \pm 0.6$ & 0.366 \\
\hline Physical-WHOQOL-BREF score (7-35) & $14.5 \pm 0.7$ & $13.4 \pm 0.7$ & $14.2 \pm 1.1$ & 0.660 \\
\hline Psychological-WHOQOL-BREF score (6-30) & $34.2 \pm 1.1$ & $32.4 \pm 1.5$ & $32.2 \pm 1.9$ & 0.631 \\
\hline Social relations-WHOQOL-BREF score (3-15) & $25.1 \pm 0.5$ & $26.1 \pm 0.7$ & $23.8 \pm 1.5$ & 0.336 \\
\hline Environment-WHOQOL-BREF score (8-40) & $12.8 \pm 1.2$ & $13.2 \pm 0.7$ & $13.1 \pm 0.5$ & 0.946 \\
\hline Global-WHOQOL-BREF score (2-10) & $6.7 \pm 0.3$ & $6.8 \pm 0.6$ & $7.2 \pm 0.3$ & 0.723 \\
\hline
\end{tabular}

Note: The results are mean (standard deviations); (DNG) Dry Needling Group; (IPG) Isquemic pressure group; (CG) control group; (VAS) visual analogue scale; (PMTrP) principal MTrP; (SMTrP ) secondary MTrP ; (WHOQOL-BREF) Short Form of WHO Quality of Life Questionnaire. Kruskal-Wallis was used to compared gender distribution among groups and ANOVA one-way was used for all the other measurements. 


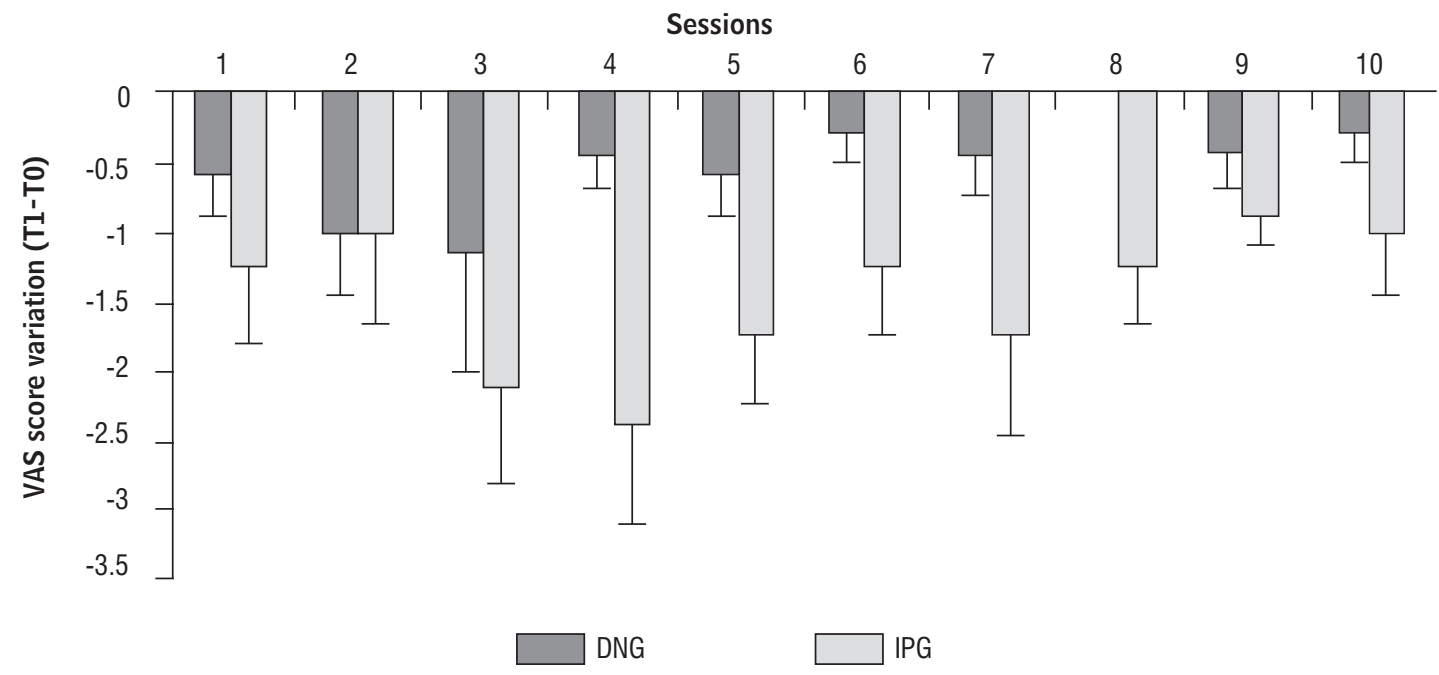

Figure 2 - VAS score variation during 10 therapeutics sessions in the the DNG underwent a dry needling and IPG underwent a ischemic pressure Error bar indicates standard error of mean (SEM). Paired sample-test

Table 2 - Change (\%) of the World Health Organization Questionnaire of Quality of Life (WHOQOL-BREF) scores of each domains from baseline

\begin{tabular}{cccc}
\hline WHOQOL-BREF & DNG & IPG & CG \\
\hline Domains & $\mathbf{N}=\mathbf{7}$ & $\mathbf{N}=\mathbf{8}$ & $\mathbf{N}=\mathbf{7}$ \\
\hline Physical & $2.0 \pm 5.6$ & $19.8 \pm 6.5$ & $-1.7 \pm 5.0$ \\
Psychological & $5.4 \pm 3.6^{\star}$ & $6.9 \pm 2.8^{\star}$ & $-5.0 \pm 3.1^{*}$ \\
Social relations & $5.5 \pm 1.9$ & $-3.2 \pm 1.4$ & $10.2 \pm 7.2$ \\
Environment & $6.2 \pm 7.9$ & $0.1 \pm 1.4$ & $-2.8 \pm 3.1$ \\
Global & $12.1 \pm 6.5$ & $19.7 \pm 18.1$ & $-0.3 \pm 9.5$ \\
\hline
\end{tabular}

Note: DNG: dry needling group; IPG: isquemic pressure group; CG: control group. "*” symbols indicate significant deviations $(p<0.05)$ for dry needling group, isquemic pressure group and control group (one-way ANOVA, LSD post hoc test).

At present, studies showed the complex aspect of quality of life since many factors influence it such as general health, day-to-day activity, mood and your view life (29). Our results demonstrated an improvement of psychological domain of the WHOQOl-BREF for all groups, this could be related with the complexity of quality of life since receive or no any intervention seems did not influence. Furthermore, the TP origin was related with a sustained contraction that compress blood vessels and causing local hypoxia $(26,30)$ and could be associated with habit and postures such as sleep position, work position, sedentary lifestyle and stress level. These aspects were not considered in our study because we did not worry to influence lifestyle change. Indeed, our findings could be influenced by this.

Some limitations of our study should be mentioned as the difference of age betweens groups, the 
inclusion of musculoskeletal pain syndrome with different origins at the same group and the absent of a minimum score for VAS. The VAS scores were significantly lower after the treatment only for IPG. However, this could be explained because subjects of this group were younger, had a higher baseline VAS score and a lower threshold of pain in comparison with DNG. Furthermore, ischemic pressure seemed to be effective in reduction of pain for this population. This is an important result because ischemic pressure is a technique of easy application and cheaper than dry needling. Also, ischemic pressure can be used in a younger population with positive effects in reduction of pain even though this musculoskeletal syndrome has different origins. Additionally, we suggest an experimental trial with a larger sample to analyze the long-term effects of these techniques.

In conclusion, dry needling and ischemic pressure could be effective in treatment of myofascial pain. Our study demonstrated that it is possible to obtain a reduction of disability and pain with both techniques.

\section{References}

1. Srbely JZ, Dickey JP, Lee D, Lowerison M. Dry needle stimulation of myofascial trigger points evokes segmental anti-nociceptive effects. J Rehabil Med. 2010;42(5):463-8.

2. Ga H, Kou HJ, Choi JH, Kim CH. Intramuscular and nerve root stimulation vs lidocaine injection to trigger points in myofascial pain syndrome. J Rehabil Med. 2007;39(5):374-8.

3. Ma C, Wu S, Li G, Xiao X, Mai M, Yan T. Comparison of miniscalpel-needle release, acupuncture needling, and stretching exercise to trigger point in myofascial pain syndrome. Clin J Pain. 2010;26(3):251-7.

4. Woolf AD, Pfleger B. Burden of major muskuloeskeletal conditions. Bull World Health Organ. 2003; 81(9):646-56.

5. Cummings M, Baldry P. Regional myofascial pain: diagnosis and management. Best Pract Res Clin Rheumatol. 2007;21(2):367-87.

6. Fouda A. Comparison between four treatment modalities for active myofascial triggers points. Plastic and Aesthetic Research. 2014;1(1):21.
7. Simons DG, Travell JG, Simons LS. Dor e disfunção miofascial: parte superior do corpo. 2a. ed. Porto Alegre: Artmed; 2005. v. 1.

8. Hiraizumi Y. Clinical condition and treatment of neck disability (katakori). New MOOK Orthop. 1999;6: 275-82.

9. Deyo RA, Phillips WR. Low back pain. A primary care challenge. Spine. 1996;21(24):2826-32.

10. Tanaka TH, Leisman G, Mori H, Nishijo K. The effect of massage on localized lumbar muscle fatigue. BMC Complement Altern Med. 2002;2:9.

11. Chou R, Huffman LH; American Pain Society; American College of Physicians. Nonpharmacologic therapies for acute and chronic low back pain: a review of the evidence for an American Pain Society/American College of Physicians clinical practice guideline. Ann Intern Med. 2007;147(7):492-504.

12. Lavelle ED, Lavelle W, Smith HS. Myofascial trigger points. Med Clin North Am. 2007;91(2):229-39.

13. Edwards J, Knowles N. Superficial dry needling and active stretching in the treatment of myofascial pain: a randomised controlled trial. Acupunct Med. 2003;21(3):80-6.

14. Hsieh YL, Kao MJ, Kuan TS, Chen SM, Chen JT, Hong CZ. Dry needling to a key miofascial trigger point may reduce the irritability of satellite MTrPs. Am J Phys Med Rehabil. 2007;86(5): 397-403

15. Aguilera FJM, Martín DP, Masanet RA, Soler LB, Morrel FB. Immediate effect of ultrasound and ischemic compression techniques for the treatment of trapezius latent myofascial trigger points in healthy subjects: A Randomized Controlled Study. J Manipulative Physiol Ther. 2009;32(7):515-520

16. Maher CG. Effective physical treatment for chronic low back pain. Orthop Clin North Am. 2004;35(1):57-64.

17. Ferguson LW, Gerwin R. Tratamento clínico da dor miofascial. Porto Alegre: Artmed; 2007.

18. Farina $S$, Casarotto $M$, Benelle M, Tinazzi M, Fiaschi A, Goldoni $\mathrm{M}$, et al. A randomized controlled study on the effect of two different treatments (FREMS AND TENS) in myofascial pain syndrome. Eura Medicophys. 2004;40(4):293-301. 
19. Meeus M, Roussel N, Truijen S, Nijs J. Reduced pressure pain thresholds in response to exercise in chronic fatigue syndrome but not in chronic low back pain: an experimental study. J Rehabil Med. 2010;42(9):884-90.

20. Fleck M. O instrumento de avaliação de qualidade de vida da organização mundial de saúde (WHOQOL 100): características e perpesctivas. Ciênc Saúde Coletiva. 2000;5(1):33-8.

21. Moreno AB, Faerstein E, Werneck GL, Lopes CS, Chor D. Propriedades psicométricas do Instrumento Abreviado de Avaliação de Qualidade de Vida da Organização Mundial da Saúde no Estudo Pró-Saúde. Cad Saude Publica. 2006;22(12):2585-97.

22. Hanten WP, Olson SL, Butts NL, Nowicki AL. Effectiveness of a home program of ischemic pressure followed by sustained stretch for treatment of myofascial trigger points. Phys Ther. 2000;80(10):997-1003.

23. Nambi G, Sharma R, Inbasekaran D, Vaghesiya A, Bhatt U. Difference in effect between ischemic compression and muscle energy technique on upper trepezius myofascial trigger points: Comparative study. Int J Health Allied Sci. 2013;2(1):17

24. Huguenin L, Brukner PD, McCrory P, Smith P, Wajswelner $\mathrm{H}$, Bennell K. Effect of dry needling of gluteal muscles on straight leg raise: a randomised, placebo controlled, double blind trial. Br J Sports Med. 2005;39(2):84-90.

25. Sterling M, Valentin S, Vicenzino B, Souvlis T, Conelly L. Dry needling and exercise for chronic whiplash - a randomised controlled trial. BMC Musculoskelet Disord. 2009;10:160.
26. Simons DG, Travell JG, Simons LS. Travell \& Simons' myofascial pain and dysfunction: the trigger point manual. 2nd ed. Baltimore: Williaws \&Wilkin; 1999.

27. Hong CZ. Treatment of myofascial pain syndrome. Curr Pain Headache Rep. 2006;10(5):345-9

28. Orlando B, Manfredini D, Bosco M. Efficacy of physical therapy in the treatment of masticatory myofascial pain: a literature review. Minerva Stomatol. 2006;55(6):355-66.

29. Wood-Dauphine S, Williams JI. The Spitzer Quality of Life Index: its performance as a measure. In: Osaba D, editor. The effect of cancer on quality of life. Montreal: CRS Press; 1991. p. 169-84.

30. Lima ICM, Seguchi HHK, Imamura M, Saito ET, Pinho CP, Imamura ST. Tratamento da lombalgia crônica pela inativação de pontos-gatilho miofasciais: experiência da Divisão de Medicina Física da FMUSP. Acta Fisiátrica. 1999;6(1):10-13.

Received: 03/17/2014

Recebido: 17/03/2014

Approved: 10/09/2014

Aprovado: 09/10/2014 